УДК 159.923.5:159.922.7

DOI https://doi.org/10.32838/2709-3093/2021.3/23

Світич C.A.

КЗВО ««Дніпровська академія неперервної освіти» Дніпропетровської обласної ради»

\title{
СТРУКТУРА СПРЯМОВАНОСТІ ВЧИТЕЛІВ ПОЧАТКОВИХ КЛАСІВ ЩОДО ВЗАЕМОДІЇ ІЗ СОМАТИЧНО ПОСЛАБЛЕНИМИ УЧНЯМИ
}

\begin{abstract}
Дослідження поводилося з метою визначення структури спрямованості педагогів початкової школи як основи формування психологічної готовності до ефективної взаємодії із соматично послабленими дітьми. Авторський опитувальник містив 12 запитань, метою було визначення структури спрямованості педагогів як співвідношення гуманістичних, ідеалістичних, прагматичних або егоцентричних орієнтацій. Аналіз результатів дає підстави зробити висновок про неналежний рівень психологічної підготовки педагогів до роботи із соматично послабленими учнями. Явно недостатнім є знаннєво-когнітивний компонент готовності, також варто акиентувати практичну відсутність навичок роботи з даною категорією дітей. Педагоги не орієнтуються у специфіиі роботи, не володіють методами та прийомами виявлення індивідуальних особливостей дітей иієї категорії. Відсутні характеристики, які дають можливість педагогам створити доброзичливу атмосферу для розвитку дітей. Спостерігається неналежне розуміння необхідності врахування особливостей соматично послаблених учнів у навчальному процесі. Менше половини педагогів мають гуманістичну спрямованість, що проявляється, зокрема, у небажанні чи невмінні ефективно взаємодіяти з учнями иієї категорії на основі партнерських відносин. Жоден із досліджуваних учителів не має високого рівня розвитку емпатійних здібностей, третина педагогів мають середній рівень емпатії, дві третини - знижений рівень емпатії. Найбільш сформованим у структурі готовності педагогів до взаємодії із соматично послабленими учнями є мотивачійний компонент, найменш сформованими є когнітивний та операційний компоненти. Психологічна підготовка має бути спрямованою на формування передусім даних компонентів.
\end{abstract}

Ключові слова: педагогічна психологія, початкова школа, соматично послаблені діти, спрямованість педагога, технології.

Постановка проблеми. Соматична ослабленість $є$ одним $з$ основних чинників, що визначає проблеми учнів загалом і в початковій школі зокрема. Тому вивчення та врахування психологічних особливостей соматично послаблених дітей молодшого шкільного віку педагогами в навчально-виховному процесі $\epsilon$ вкрай важливим. Велике значення для подолання негативних тенденцій в особистісному розвитку соматично послаблених дітей та для їх успішного навчання має особистість учителя, його готовність до взаємодії $з$ дітьми цієї категорії. Водночас педагогічна практика і емпіричні дослідження показують суттєві проблеми в готовності педагогів до використання специфічних підходів та методів роботи iз соматично ослабленими учнями $[1 ; 5]$. Часто педагоги не розуміють проблем, що виникають у таких дітей, не можуть надати їм належної психолого-педагогічної підтримки і допомоги.

Аналіз останніх досліджень і публікацій. Емпіричні дослідження стану дітей молодших класів із використанням тесту Люшера, здійснені вітчизняними фахівцями, показують наявність високого рівня психологічної напруги (24\%), тривожності (32\%), психічної втоми $(29,6 \%)$, водночас максимальний рівень стресу зазначений у $67 \%$ дітей, що, як вказують дослідники, «підтверджує стресогенність соціального оточення ЗНЗ, особливо для дітей, які почали навчатись. I це поєднується із проблемою високого рівня захворювань у дітей старшого дошкільного та молодшого шкільного віку» [6, с. 62]. Слушно зазначають вітчизняні дослідники В. Неділько та С. Руденко, що «першочергове завдання полягає у впровадженні до педагогічної практики охорони здоров'я технологій для запобігання (мінімізації) негативному впливу чинників ризику, що передбачає обов'язкове врахування функціональних можливостей дітей, індивідуальних особливостей їхнього реагування на умови навчального середовища» $[6$, с. 61].

Виникнення труднощів у навчанні, а також емоційного неблагополуччя дітей у школі внаслідок поєднання чинників стресогенності та соматичної ослабленості досліджується в роботах М. Буянова, Б. Воронкова, О. Захарова, Д. Ісаєва, В. Кагана й 
інших. У низі досліджень Г. Аріної, М. Коваленко, А. Міхеєвої, Л. Долинської й інших фахівців показано, що водночас у соматично послаблених дітей відбуваються негативні особистісні зміни - знижується самооцінка, підвищується рівень тривожності тощо. Науковцями порушувалися питання психологічної підготовки вчителів до взаємодії 3 такими дітьми [3; 4; 8]. Однак традиційно основна увага приділяється загальним питанням організації навчального процесу, віковим особливостям дітей, але не розкривається специфіка роботи 3 дітьми, які потребують особливої уваги і відповідного інструментарію педагогічного впливу.

Постановка завдання. Метою статті $\epsilon$ визначення структури спрямованості педагогів початкової школи як основи формування психологічної готовності до ефективної взаємодії із соматично послабленими дітьми.

Виклад основного матеріалу дослідження. Для визначення рівня сформованості компонентів психологічної готовності вчителів початкових класів до взаємодії із соматично послабленими учнями було розроблено авторський опитувальник. Емпіричним дослідженням було охоплено 388 учителів початкових класів, які проходили курси підвищення кваліфікації у Дніпропетровському обласному інституті післядипломної педагогічної освіти. Авторський опитувальник містив 12 запитань, метою було визначення структури спрямованості педагогів як співвідношення гума- ністичних (далі - Г), ідеалістичних (далі - I), прагматичних (далі - П) або егоцентричних (далі - E) орієнтацій [9].

Виявилося, що менше половини $(46,8 \%)$ учителів початкових класів мають гуманістичну спрямованість, 29,1\% педагогів мають егоцентричну спрямованість, 21,9\% - прагматичну, 2,3\% - ідеалістичну. Ця тенденція $є$ досить несприятливою.

Під час проведення аналізу залежності спрямованості педагогів від їхньої кваліфікаційної категорії виявилося, що гуманістична спрямованість найбільше представлена в педагогів, які мають вищу категорію, що можна пояснити їхнім великим досвідом і знаннями, та в педагогів без категорії. Для наочності ці дані представлені в діаграмі (рис. 1).

Гуманістична спрямованість переважає у структурі спрямованості частіше в педагогів зі стажем роботи до 5 років та більше 25 років.

Так, гуманістичну спрямованість мають $31,6 \%$ педагогів, які мають стаж роботи до 5 років, $21,3 \%$ - зі стажем від 6 до 15 років, $21,0 \%$ - зі стажем від 16 до 25 років, 56,7\% - зі стажем більше 25 років.

Наступним кроком нашого дослідження було визначення емпатійних здібностей педагогів за методикою діагностики рівня емпатійних здібностей В. Бойко. У структурі емпатії за методикою В. Бойко оцінювалися такі параметри: раціональний канал емпатії, емоційний канал, інтуїтивний

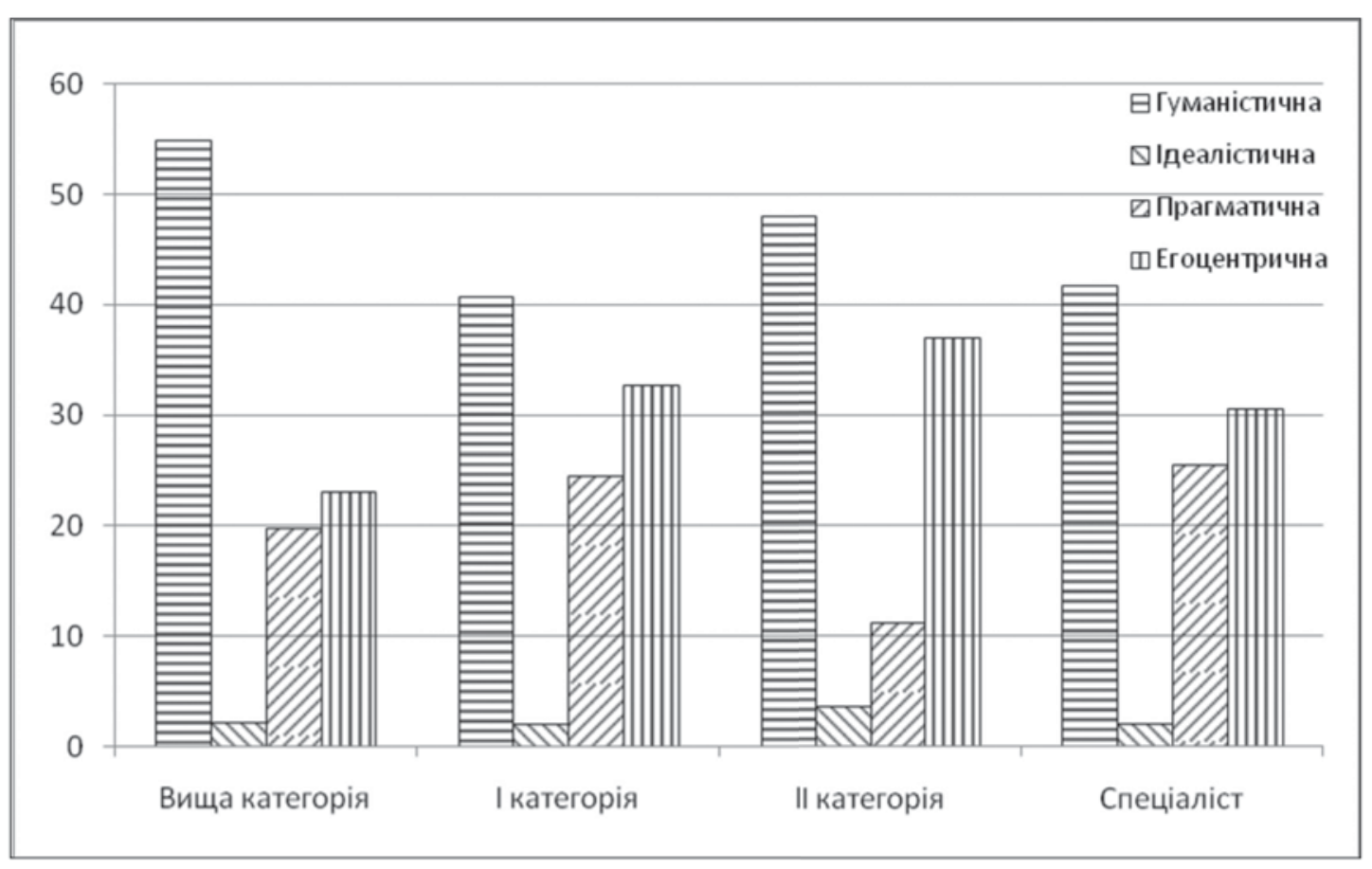

Рис. 1. Спрямованість педагогів різних кваліфікаційних категорій (\%) 
канал, настанови, що сприяють або перешкоджають емпатії, проникаюча здатність в емпатії, ідентифікація.

Виявилося, що високий рівень емпатійних здібностей не має жодний із педагогів, які брали участь у дослідженні, 17\% досліджуваних мають середній рівень емпатійних здібностей, 68,3\% знижений, 14,7\% - дуже низький рівень.

Під час оцінювання рівня емпатії педагогів залежно від їхньої освіти виявилося, що у вчителів із вищою освітою рівень емпатії $є$ трохи вищим: середній рівень емпатії відзначався в 17,8\% педагогів із вищою освітою i 14,7\% у педагогів, які мають середню спеціальну освіту, а знижений і дуже низький рівні частіше спостерігалися в педагогів із середньою освітою. Але ця різниця є незначною. Кількість учителів із дуже низьким рівнем емпатійних здібностей коливалася від 14,3\% серед тих, хто має вищу категорію, до $15,3 \%$ серед «спеціалістів».

Під час дослідження сформованості окремих параметрів емпатії виявилося, що найбільш розвиненим $є$ емоційний канал; менше - інтуїтивний канал емпатії й ідентифікація; проникаюча здатність, настанови, що сприяють емпатії, та раціональний канал емпатії у структурі емпатії розвинені найменше (табл. 2.21).

Усі параметри у структурі емпатії розвинені не досить: високий рівень сформованості емоційного каналу емпатії зазначено у 39,6\% досліджуваних, інтуїтивного каналу - у 17,4\%, ідентифікації - у $13,1 \%$, проникаючої здатності - у 8\%, настанов, що сприяють емпатії, - у 7,5\%, раціонального каналу емпатії - у 4,9\%.

У педагогів із вищою освітою більш розвинені такі параметри у структурі емпатії, як інтуїтивний та раціональний канали емпатії; емоційний канал емпатії й настанови у вчителів, які мають вищу освіту, і в тих, що мають середню спеціальну освіту, розвинені приблизно однаково; високий рівень проникаючої здатності й ідентифікації спостерігається дещо частіше в педагогів 3 вищою освітою, але середній рівень цих показників частіше спостерігається у вчителів, що мають середню освіту.

Ці дані свідчать про те, що педагоги з вищою освітою більше, ніж ті, що мають середню освіту, здатні спрямовувати свою увагу на стан та проблеми учня; інтуїтивно ухвалювати правильні рішення щодо вибору підходу до дитини в умовах дефіциту часу. Під час оцінювання рівня розвитку складників емпатії педагогів залежно від їхньої кваліфікаційної категоpiï виявилося, що у вчителів, які мають вищу кваліфікаційну категорію, частіше спостерігається високий рівень сформованості настанов, що сприяють емпатії. Цікавим є той факт, що високий рівень сформованості всіх складових частин емпатії частіше спостерігається в педагогів із педагогічним стажем 5-25 років. Це, можливо, пояснюється тим, що молоді спеціалісти ще не мають досить практичного досвіду, а в педагогів, які відпрацювали більше 25 років, знижується здатність до емпатії внаслідок емоційного вигоряння.

Але, як зазначалося вище, як загальний рівень емпатії, так і рівень розвитку іï окремих складових частин є досить низькими для всіх педагогів.

Отримані дані свідчать про те, що педагоги часто не здатні сконцентрувати увагу на конкретній дитині, оцінити іiі фізичний та емоційний стан, не бачать іiі проблем, не вміють або не бажають ставити себе на місце дитини і створювати доброзичливу атмосферу, тому не можуть надати їй необхідної психолого-педагогічної допомоги в разі появи труднощів.

Краще за інші в учителів розвинений емоційний канал емпатії, що свідчить про здатність педагогів співпереживати, але їхні настанови щодо небажання заглиблюватися у проблеми дітей, прагнення перекласти вирішення цих проблем на батьків, уникати особистісного спілкування перешкоджають дії емпатичних каналів.

Наступним етапом було визначення рівнів сформованості структурних компонентів психологічної готовності до взаємодії із соматично послабленими учнями (когнітивний, операційний, мотиваційний і особистісний).

Умовно нами було виділено п'ять рівнів: високий, вище середнього, середній, нижче середнього та низький. Кожному рівню готовності давались якісна характеристика й оцінка в балах.

Відповіді на запитання анкети оцінювалися за п’ятибальною шкалою: 5 балів - високий рівень, 4 бали - вище середнього, три бали - середній, два бали - нижче середнього, один бал - низький рівень (таблиця 1).

Найбільш сформованим у педагогів виявився мотиваційний компонент готовності, найменш сформованими - когнітивний та операційний.

Усі компоненти психологічної готовності (мотиваційний, когнітивний, операційний і особистісний) є більш сформованими в педагогів, які мають вищу освіту, ніж у тих, хто має середню спеціальну. 
Таблиця 1

Розподіл педагогів за ступенем сформованості в них компонентів готовності залежно від їхньої кваліфікаційної категорії (\%)

\begin{tabular}{|c|c|c|c|c|c|}
\hline \multirow{2}{*}{ Компонент } & \multirow{2}{*}{ Рівень } & \multicolumn{4}{|c|}{ Кваліфікаційна категорія } \\
\hline & & Вища & I & II & Спеціаліст \\
\hline \multirow{5}{*}{ Мотиваційний } & Високий & 6,6 & 2,1 & - & 6,1 \\
\hline & Вище середнього & 51,6 & 46,9 & 59,3 & 53,1 \\
\hline & Середній & 37,4 & 44,9 & 37,0 & 38,8 \\
\hline & Нижче середнього & 4,4 & 6,1 & 3,7 & 2,0 \\
\hline & Низький & - & - & - & - \\
\hline \multirow{5}{*}{ Когнітивний } & Високий & - & - & - & - \\
\hline & Вище середнього & - & - & - & - \\
\hline & Середній & 19,8 & 14,3 & 3,7 & 8,2 \\
\hline & Нижче середнього & 74,7 & 75,5 & 77,8 & 84,7 \\
\hline & Низький & 5,5 & 10,2 & 18,5 & 7,1 \\
\hline \multirow{5}{*}{ Операційний } & Високий & - & - & - & - \\
\hline & Вище середнього & 1,1 & - & - & - \\
\hline & Середній & 19,8 & 8,1 & 7,4 & 10,2 \\
\hline & Нижче середнього & 73,6 & 77,6 & 63,0 & 73,5 \\
\hline & Низький & 5,5 & 14,3 & 29,6 & 16,3 \\
\hline \multirow{5}{*}{ Особистісний } & Високий & - & - & - & - \\
\hline & Вище середнього & 38,0 & 24,1 & 33,3 & 34,1 \\
\hline & Середній & 57,6 & 72,2 & 66,7 & 62,2 \\
\hline & Нижче середнього & 4,3 & 3,7 & - & 3,7 \\
\hline & Низький & - & - & - & - \\
\hline
\end{tabular}

Когнітивний і операційний компоненти є більш сформованими в педагогів, які мають вищу категорію, а найменш сформованими - у вчителів другої категорії. Простежується тенденція зростання рівня сформованості мотиваційного, когнітивного й операційного компонентів психологічної готовності педагогів разом зі збільшенням педагогічного стажу. Аналіз рівнів сформованості структурних компонентів психологічної готовності педагогів до взаємодії із соматично послабленими учнями дозволив виявити найменш сформовані компоненти даної готовності: когнітивний і операційний. Найбільш сформованим виявився мотиваційний компонент.

Після визначення рівня сформованості компонентів психологічної готовності була проведена оцінка загальної готовності вчителів до роботи 3 дітьми цієї категорії шляхом сумування отриманих балів за всіма компонентами готовності.

За результатами констатувального етапу емпіричного дослідження виявлено, що найбільш представленим рівнем психологічної готовності вчителів початкових класів до взаємодії із соматично послабленими учнями в даній виборці $\epsilon$ середній $(52,5 \%), 46,6 \%$ педагогів мають рівень готовності нижче середнього, лише $0,9 \%$ учителів мають рівень психологічної готовності вище середнього. Високого рівня готовності не досяг жодний із педагогів, які брали участь у дослідженні.

Цікавим $є$ той факт, що серед педагогів, які мають вищу освіту, менший відсоток $(50,2 \%)$ мають середній рівень готовності порівняно 3 кількістю педагогів, які мають середню спеціальну освіту (59,5\%). Водночас більша частина вчителів з вищою освітою $(48,5 \%)$ частіше мають рівень готовності нижче середнього порівняно 3 учителями, які мають середню спеціальну освіту (40,5\%). Кількість педагогів із вищою освітою, які мають рівень готовності вище середнього, становить $1,2 \%$, у вчителів, які мають середню спеціальну освіту, цей рівень відсутній.

Під час порівняння рівнів готовності педагогів залежно від їхньої кваліфікаційної категорії було виявлено, що відсоток педагогів, які мають середній рівень готовності, є більшим серед педагогів, які мають вищу кваліфікаційну категорію та категорію «спеціаліст» $(58,7$ та 54,2\%). Кількість учителів першої та другої категорій, які мають середній рівень готовності, становить 50,0 та 35,9\%.

Рівень готовності нижче середнього мають $38,0 \%$ педагогів вищої категорії, 45,9\% педагогів, які мають категорію «спеціаліст». Серед педагогів першої та другої категорій цей відсоток вищий - 
50,0 та $64,1 \%$ відповідно. Рівень готовності вище середнього мають 3,3\% педагогів вищої категорії, у вчителів інших категорій цей рівень готовності не представлений. Під час розгляду рівня готовності педагогів залежно від стажу роботи виявилося, що зі збільшенням стажу роботи показники готовності до взаємодії із соматично послабленими учнями дещо збільшуються.

Так, рівень готовності нижче середнього мають $50,9 \%$ учителів зі стажем роботи до 5 років, $48,4 \%$ зі стажем від 6 до 15 років, 47,1\% - зі стажем від 16 до 25 років, 42,3\% - зі стажем роботи 26 років і більше. Середній рівень готовності мають 49,1\% учителів зі стажем роботи до 5 років, $51,6 \%$ - зі стажем від 6 до 15 років, 51,0\% - зі стажем від 16 до 25 років, $56,7 \%$ - зі стажем роботи 26 років і більше. Рівень готовності вище середнього мають 2,0\% педагогів зі стажем від 16 до 25 років, 1,0\% зі стажем роботи 26 років і більше.

Висновки. Аналіз розподілу педагогів за рівнями готовності до взаємодії із соматично послабленими учнями дозволив зробити висновок, що жоден із 320 респондентів не має високого рівня психологічної готовності до даного виду роботи, незначний відсоток педагогів $(1,2 \%)$ мають рівень психологічної готовності вище середнього, більшість - середній рівень та нижче середнього $(52,5$ та 46,6\%). Отже, аналіз результатів підтвердив актуальність проблеми психологічної підготовки педагогів до роботи із соматично послабленими учнями. Це цілком відповідає наявним у вітчизняній науковій літературі даним. Дослідники відмічають, що вчителям не вистачає знань та умінь під час взаємодії із цією категорією дітей. Педа- гоги не тільки погано орієнтуються в сутності даної проблеми, але й не володіють методами та прийомами виявлення індивідуальних особливостей дітей цієї категорії, побудови навчального процесу з урахуванням цих особливостей, не вміють або не бажають ставити себе на місце дитини, створювати доброзичливу атмосферу [8, с. 46]. У педагогів відмічається недостатнє розуміння важливості врахування психологічних особливостей соматично послаблених учнів у педагогічній роботі, а інколи і негативне ставлення до цих дітей, ігнорування їхніх індивідуальних особливостей $[2$, c. 21]. У нашому дослідженні емпірично встановлено таке:

1) менше половини педагогів мають гуманістичну спрямованість, що може проявлятись у небажанні або невмінні ефективно взаємодіяти 3 учнями цієї категорії на основі партнерських відносин;

2) жоден із досліджуваних учителів не має високого рівня розвитку емпатійних здібностей, третина педагогів мають середній рівень емпатії, більшість (68,3\%) мають знижений рівень емпатії.

У зв'язку з тим, що ступінь сформованості структурних компонентів психологічної готовності $є$ різним, психологічна підготовка повинна бути спрямованою на формування передусім найменш сформованих компонентів (когнітивний i операційний), особливо з орієнтацією на завдання формування соціального інтелекту [7, с. 39]. Для цього має бути розроблена спеціальна програма психологічної підготовки вчителів початкових класів до взаємодії із соматично послабленими учнями.

\section{Список літератури:}

1. Бочелюк В., Турубарова А. Психологія людини з обмеженими можливостями. Київ, 2016. 262 с.

2. Засенко В. Освіта «особливих» дітей: стан і перспективи розвитку. Педагогіка і психологія. 2016. № 4. C. 19-23.

3. Котелянець Ю. Формування толерантного інклюзивного середовища в початковій школі. Науковий вісник Начіонального університету біоресурсів $i$ природокористування України. Серія «Педагогіка, психологія, філософія». 2016. Вип. 253. С. 115-121.

4. Литвин I. Роль педагога-фасилітатора в гуманізації ціннісно-смислової сфери особистості з особливими освітніми потребами. Педагогічний вісник. 2016. № 4. С. 10-11.

5. Мосина Н. Особенности развития самосознания часто болеющего младшего школьника. Красноярск, 2007. 144 с.

6. Неділько В., Руденко С. Здоров'я та розвиток дітей старшого дошкільного і молодшого шкільного віку. Освіта та розвиток обдарованої особистості. 2013. № 3. С. 60-63.

7. Романенко М., Братаніч Б., Куций А. Соціальний інтелект як предмет філософських та психологічних досліджень. Гілея : науковий вісник. 2019. Вип. 140 (2). С. 37-40.

8. Савчук 3., Москалюк Л. Психологічна готовність учителя до роботи в інклюзивному просторі: теоретичний аспект. Особлива дитина: навчання і виховання. 2017. № 2. С. 42-47.

9. Семиченко В., Світич С. Формування готовності вчителів до роботи із соматично послабленими учнями в системі підвищення кваліфікації. Вісник Національного авіаційного університету. Серія «Педагогіка. Психологія». 2017. Т. 2. № 11. С. 138-146. 


\section{Svitich S.A. STRUCTURE OF PRIMARY SCHOOL TEACHERS' INTERIORIZATION REGARDING INTERACTION WITH SOMATICALLY WEAKENED STUDENTS}

The study was conducted in order to determine the structure of orientation of primary school teachers as a basis for the formation of psychological readiness for effective interaction with somatically impaired children. The author's questionnaire included 12 questions, the purpose was to determine the structure of teachers' orientation as a ratio of humanistic, idealistic, pragmatic or egocentric orientations. The analysis of the results gives grounds to draw a conclusion about the insufficient level of psychological preparation of teachers to work with somatically weakened students. The knowledge and cognitive component of readiness is clearly insufficient, and the practical lack of skills to work with this category of children should also be emphasized. Teachers are not guided by the specifics of the work, do not have the methods and techniques to identify individual characteristics of children in this category. There are no characteristics that allow teachers to create a friendly atmosphere for children's development. There is a lack of understanding of the need to take into account the characteristics of somatically impaired students in the learning process. Less than half of teachers have a humanistic orientation, which is manifested, in particular, in the unwillingness or inability to interact effectively with students in this category on the basis of partnerships. None of the studied teachers has a high level of development of empathic abilities, a third of teachers have a medium level of empathy, two thirds - a low level of empathy. The motivational component is the most formed in the structure of teachers' readiness to interact with somatically weakened students, the cognitive and operational components are the least formed. Psychological training should be aimed primarily at the formation of these components.

Key words: pedagogical psychology, primary school, somatically weakened children, teacher orientation, technologies. 